\title{
ЛІНГВОДИДАКТИЧНІ АСПЕКТИ МОВНОЇ ПІДГОТОВКИ МАЙБУТНІХ ФАХІВЦІВ
}

Голівер Н. О. Лінгводидактичні аспекти мовної підготовки майбутніх фахівців.

У статті на основі узагальнення, зіставлення наукової інформації конкретизовано поняття «лінгводидактика», «комп'ютерна лінгводидиктика», розкрито засади формування іншомовної комунікативної компетенції мовної особистості.

Ключові слова: лінгводидактика, комп’ютерна лінгводидиктика, комунікативна компетенція, іншомовна професіоналізація.

Голивер Н. А. Лингводидактические основы языковой подготовки будущих специалистов.

В статье на основе обобщения, сравнения научних данных конкретизированы понятия «лингводидактика», «компьютерная лингводидактика». Рассмотрены основы формирования иноязычной коммуникативной компетенции языковой личности.

Ключевые слова: лингводидактика, компьютерная лингводидактика, коммуникативная компетенция, иноязычная профессионализация.

Holiver N. O. Lingvodidactic basis of perspective specialists' language training.

On the basis of scientific information comparative analysis the notions «lingvodidactics», «computer based lingvodidactics» are grounded. The foundations of language personality foreign language competence are considered.

Key words: lingvodidactics, computer based lingvodidactics, communicative competence, foreign language proficiency.

У процесі інтеграції України до світової спільноти змінилися вимоги ринку праці до фахівців різних галузей i особливо учасників зовнішньоекономічної діяльності, професіоналізм яких безпосередньо залежить від рівня та якості іншомовної професійної комунікативної компетенції фахівця, готового вступати в професійно-ділове спілкування 3 представниками інших культур.

Формуванню іншомовної професійної комунікативної компетенції сприяє переосмислення деяких педагогічних положень з позиції останніх досягнень теорії та практики навчання іноземної мови в немовній вищій школі: включення України в Болонський процес, основною метою якого $є$ гармонізація національних систем вищої освіти, що сприяє формуванню єдиного європейського ринку висококваліфікованої праці; профілізація української освіти, спрямована на реалізацію державного освітнього стандарту з урахуванням профілю ВНЗ; підвищення статусу предмета «Ноземна мова», внесення його до державних освітніх стандартів як обов'язкового; модернізація української освіти, спрямована на введення дворівневої системи навчання: бакалаврмагістр; використання в навчальному процесі, поряд 3 обов'язковими програмами, продиктованими стандартом освіти, факультативних, авторських програм.

Однак кроки, які вживалися щодо вдосконалення системи навчання іноземної мови в немовній вищій школі, нерідко призводили до декларативності, незавершеності та розпливчастості цільових настанов, у яких іншомовна професіоналізація не знайшла реального відображення.

Подібна ситуація висуває вимоги іншомовної професіоналізації і до викладача іноземної мови, який нині не може дистанціюватися від спеціальної дисципліни (теплоенергетики, економіки, інформатики тощо), апелюючи до отриманої лінгвістичної освіти.

На сучасному етапі мова зі спеціальності все більше перетворюється на мову для спеціальності. 
У сформованих умовах, коли, з одного боку, знання тільки іноземної мови стали недостатніми для значної кількості фахівців, а з іншого, - сучасному професіоналові не обійтися без володіння певним рівнем мови, потрібна конкретизація й актуалізація мети професійно орієнтованого навчання іноземної мови. Ураховуючи спрямованість на формування здатності до міжкультурного спілкування, мету навчання іноземної мови фахівців необхідно фокусувати на професійно-діловому складнику.

Примітним $\epsilon$ те, що якщо міжкультурна компетенція розкриває відмінність культур і виховує толерантність по відношенню до деколи суперечливого сприйняття одного і того ж явища в різних народів, то професійна компонента дозволяє виявити більше подібностей, ніж відмінностей. Мова науки, технології, бізнесу, а особливо терміни, швидше ріднять представників різних професій, ніж роз'єднують, і досягнення в певній галузі знань викликають інтерес фахівців усього світу незалежно від їх національної приналежності.

Отже, з одного боку, високі вимоги, що висуваються до рівня освіти фахівців, і накопичений багатий емпіричний досвід багатьох ВНЗ України в системі навчання іноземної мови в немовних ВН3, а 3 іншого, - нестабільність і низька результативність проведених реформ, що призвели до необхідності розроблення теоретико-методологічних основ навчання мови для професійних цілей, покликаних усунути такі суперечності: між соціальним замовленням суспільства на висококваліфікованих фахівців і недостатнім рівнем і якістю їхньої іншомовної професійної комунікативної компетенції; між об'єктивними потребами особистості фахівця i декларативністю безперервного особистісно зорієнтованого навчання мови спеціальності; між традиційною методикою навчання іноземних мов фахівців і сучасними вимогами до рівня їхніх знань та лінгвопрофессіональних умінь; між накопиченою багатою практикою навчання іноземних мов фахівців і недостатньою розробленістю науково-теоретичних основ їх навчання у сфері професійної комунікації.

Аналіз сучасних вітчизняних і зарубіжних публікацій свідчить про те, що, починаючи 3 70-х років, методична наука прагне зміцнити свої теоретичні основи за рахунок здійснення інтегративного підходу до визначення основних закономірностей педагогічного процесу навчання іноземних мов 3 метою створення об'єктивної наукової основи для оцінки ефективності методів навчання та їх подальшого розвитку. Іншими словами, констатуємо загальну спрямованість на посилення теоретичної бази методичної науки за рахунок лінгводидактичних даних, що дозволяють зорієнтуватися в поліфонії методичних думок, які мають часом суперечливий характер і нерідко недостатньо обгрунтовані в теоретичному плані. Однак однозначної думки щодо статусу лінгводидактики як науки, іiі об'єкта і предмета дослідження немає.

Як відомо, лінгводидактика - розділ педагогіки, що розробляє теорію освіти, навчання й виховання. На наш погляд, необхідно розглянути цей термін, який не має однозначної дефініції і трактується по-різному. Як наука, лінгводидактика в Україні розвивається вже понад століття, хоча термін з'явився в 70-х рр. минулого століття завдяки російському науковцю М. Шанському. У загальному трактуванні лінгводидактика - «термін, що вживається на позначення функціональної частини методики, у якій досліджуються закономірності оволодіння мовою, розв'язуються питання змісту курсу на основі лінгвістичних досліджень, вивчаються труднощі засвоєння мовного матеріалу та їх причини, визначаються принципи i методи навчання, шляхи i засоби формування комунікативної компетенції» [4, с. 156].

У певному сенсі таке розуміння лінгводидактики як науки $є$ близьким до окремих аспектів прикладної лінгвістики (Applied Linguistics), яке розвивається в англомовних країнах.

Різноманіття варіантів навчання іноземних мов і навчальних засобів висунуло нові вимоги до вчителя / викладача, якому в нових педагогічних умовах необхідно вміти діяти не за суворо запропонованими правилами, а відповідно до власного усвідомленого вибору 
3 числа можливих методичних систем тієї, яка більшою мірою адекватна умовам навчання. Для цього йому також необхідно знати, що слід розуміти під «володінням мовою» і за якими законами протікає процес оволодіння мовою в навчальних умовах. Нова освітня «ідеологія» спонукала до переосмислення методичних проблем з точки зору процесів оволодіння учнем мовою в різних навчальних умовах. Ідеться про отримання об’єктивних даних оволодіння мовою, підкріплених не стільки емпіричними дослідженнями на матеріалі конкретної мови (ці дані випливають 3 галузі приватної методики), скільки глибоким теоретичним обгрунтуванням усіх чинників, що впливають на процес оволодіння іноземною мовою незалежно від конкретних умов навчання.

Наявність зазначених суперечностей зумовила мету статmi - розкрити теоретикометодологічні основи процесу навчання іноземної мови для професійних цілей, якими опікується професійна лінгводидактика.

Процес оволодіння мовою в навчальних умовах є предметом досліджень і психологів, $\mathrm{i}$ психолінгвістів, і лінгвістів, і методистів. Водночас підійти до осмислення цього процесу лише з позиції тієї чи іншої окремої дисципліни - означяє не отримати повної картини, що відтворює механізм оволодіння мовою з навчальною метою. Зробити це дозволяє, на думку науковців, тільки лінгводидактика, оскільки вона, будучи інтегративною наукою, покликана розкрити як опис механізмів оволодіння мовою, так і специфіку управління цими механізмами в навчальних умовах.

В основу розробленої В. Райніке концепції покладено ідею про існування трьох самостійних і разом з тим взаємопов'язаних наукових дисциплін, що складають теорію навчання іноземних мов: 1) теорії оволодіння мовою, або лінгводидактики; 2) дидактики іноземної мови; 3) методики навчання конкретної мови, або приватної методики [5, c. 257-263].

Спільність названих вище наукових дисциплін зумовлена тим, що в центрі їх дослідження перебуває здатність людини користуватися мовним кодом у комунікації. Висування здатності людини здійснювати мовне спілкування в ранг центральної категорії названих вище наук є досить прогресивним, оскільки тільки в цьому випадку можна говорити про те, що предметом інтересів науковців, що опікуються багатоаспектними проблемами навчання іноземних мов, стає мовна особистість.

Говорячи про специфіку наукових галузей, які є складниками теорії навчання іноземних мов, зауважимо, що вона (специфіка) пов'язана з різним ставленням кожної з них до головної категорії дослідження - здатності до мовного спілкування. Так, лінгводидактика вивчає проблеми, пов'язані з аналізом, управлінням і моделюванням процесів оволодіння мовою. При цьому йдеться про опис і пояснення механізмів і внутрішніх структурно-утворюючих процесів оволодіння мовою, як рідною, так і іноземною. Для фахівця, що досліджує дидактичні питання, здатність до мовного спілкування постає стратегічною метою навчання, в той час як предметом приватної методики є процес передавання і засвоєння (вивчення) здатності до спілкування мовою, яка вивчається з урахуванням конкретних умов навчання.

Оскільки методист розв'язує питання формування здатності до спілкування мовою, що вивчається, він повинен володіти знаннями особливостей процесу оволодіння цією здатністю. Однак сама методика не формує подібних знань, вона бере їх з інших галузей знань, і перш за все з дидактики. Остання є наукою про загальні закономірності навчання будь-якої, без винятку, мови [5, с. 12-18].

Отже, актуальність лінгводидактичних досліджень зумовлена необхідністю створення об'єктивної наукової основи задля оцінки ефективності методів навчання і їх подальшого розвитку, методів, в основі яких лежить насамперед ідея про формування мовної особистості.

Це означає, що ця наука покликана розробляти основи методології навчання іноземних мов стосовно різних результатів певного процесу, дозволяє виявити об'єктивні закономірності, згідно з якими повинна будуватися модель навчання іноземних мов, у центрі якої перебуває білінгвальна (полілінгвальна) і бікультурна (полікультурна) мовна 
особистість учня. Лінгводидактика як наука покликана осмислити й описати лінгвокогнітивну структуру мовної особистості, обгрунтувати умови і закономірності іiі розвитку як бажаного результату в процесі викладання та вивчення іноземної мови, а також вивчити специфіку як об'єкта засвоєння / викладання (мови, мовної картини світу носія мови, що вивчається), так і взаємодію всіх суб'єктів цього процесу, природу помилок (мовних, лінгвокраїнознавчих i, більш широко, культурологічних) і механізм їх усунення.

Перспективу подальших досліджень вбачаємо в дослідженні особливостей навчання і засвоєння мови в контексті багатомовності, індивідуальних і культурних особливостей студентів, їхньої вікової специфіки, факторів, що визначають повноту / неповноту володіння мовою.

\section{Література}

1. Нісімчук А. С. Сучасні педагогічні технології: [навч. посіб.] / А. С. Нісімчук, О. С. Падалка, О. Т. Шпак. - К. : Просвіта, Книга пам'яті України, 2000. - 368 с. 2. Пиотровская К. Р. Современная компьютерная лингводидактика / К. Р. Пиотровская // Научно-техническая информация. Сер. 2. Информационные процессы и системы. - М., 1991. - № 4. - 33 с. 3. Полат E. С. Интернет в гуманитарном образовании : [учеб. пособ. для студ. высших учебных заведений] / Е. С. Полат, М. В. Моисеева, А. Е. Петров ; под ред. Е. С. Полат. - М. : Владос, 2001. - 272 с. 4. Levi M. CALL: Context and Conceptualisation [Electron. resourse] / M. Levi. - Oxford: Oxford University Press, 1997. - Режим доступа : http://www.llas.ac.uk/resources/ 5. Reinecke W. Einige Bemerkungen zur Linquodidaktik als Bestandteil einer Theorie des Fremdsprachenunterrichts // Deutsch als Fremsprache(16). 1979. - H. 5. S. 257-263. 6. Reinecke W. Linguodidaktik Zur Theorie des Fremdsprachenerwerbs. Leipzig: VEB Verlag Enzyklopaedie, 1985. - 199 s. 7. Roche J. Interkulturelle Sprachdidaktik Gunter. Narr Verlag Tuebingen, 2001. - 248 s.

УДК 378.14.001.76:372.213.3

В. В. Городиська, кандидат пед. наук, ст. викладач, Дрогобиџький державний педагогічний університет імені Івана Франка

\section{ВИКОРИСТАННЯ ІННОВАЦЙНИХ ТЕХНОЛОГІЙ У ПІДГОТОВЦІ МАЙБУТНІХ ВИХОВАТЕЛІВ У ПЕДАГОГІЧНИХ ВНЗ}

Городиська В. В. Використання інноваційних технологій у підготовці майбутніх вихователів у педагогічних ВНЗ.

У статті проаналізовано інноваційні технології у підготовці майбутніх вихователів у педагогічних ВН3, зроблено акцент на необхідності використання мультимедії як засобу й кейстехнології як методу навчання, оскільки вони сприяють пізнанню значного обсягу інформації, ознайомлюють із новітніми освітніми технологіями та відповідають сучасним запитам студентів майбутніх вихователів ДНЗ.

Ключові слова: інновація освіти, мультимедійні технології, мультимедійні презентації, кейсметод, підготовка майбутніх вихователів.

Городиская В. В. Использование инновационных технологий $\quad$ в $\quad$ подготовке будущих воспитателей в педагогических вузах.

В статье проанализированы инновационные технологии в подготовке будущих воспитателей в педагогических вузах, сделан акцент на необходимости использования мультимедиа как средства и кейс-технологии как метода обучения, поскольку они помогают познанию значительного объема информации, знакомят с новейшими образовательными технологиями и отвечают современным запросам студентов - будущих воспитателей ДУЗ.

Ключевые слова: инновация образования, мультимедийные технологии, мультимедийные презентации, кейс-метод, подготовка будущих воспитателей. 